\title{
A REALIDADE DOS CONFLITOS NO JUDICIÁRIO E O NOVO CPC
}

RENNAN THAMAY ${ }^{1}$

ANDERSON GREJANIN ${ }^{2}$

VANDERLEI GARCIA JUNIOR ${ }^{3}$

SUMÁRIO: Introdução; 1. Os Conflitos no Poder Judiciário; 2. Do

Devido Processo Legal; 3. Do Contraditório e a Ampla Defesa; 4. A

Motivação das Decisões Judiciais; 5. Da Coisa Julgada Relativizada;

Conclusão; Referências Bibliográficas.

\footnotetext{
${ }^{1}$ Pós-Doutor pela Universidade de Lisboa. Doutor em Direito pela PUC/RS e Università degli Studi di Pavia. Mestre em Direito pela UNISINOS e pela PUC Minas. Especialista em Direito pela UFRGS. É Professor Titular do programa de graduação e pós-graduação (Doutorado, Mestrado e Especialização) da FADISP. É Professor da pós-graduação (lato sensu) da PUC/SP. Foi Professor assistente (visitante) do programa de graduação da USP e Professor do programa de graduação e pós-graduação (lato sensu) da PUC/RS. Presidente da Comissão de Processo Constitucional do IASP (Instituto dos Advogados de São Paulo). Membro do IAPL (International Association of Procedural Law), do IIDP (Instituto Iberoamericano de Derecho Procesal), do IBDP (Instituto Brasileiro de Direito Processual), IASP (Instituto dos Advogados de São Paulo), da ABDPC (Academia Brasileira de Direito Processual Civil), do CEBEPEJ (Centro Brasileiro de Estudos e Pesquisas Judiciais), da ABDPro (Associação Brasileira de Direito Processual) e do CEAPRO (Centro de Estudos Avançados de Processo). Advogado, consultor jurídico e parecerista.

${ }^{2}$ Mestrando em Direito pela Faculdade Autônoma de Direito - FADISP. Bolsista CAPES-PROSUP. Especialista em Direito Constitucional pela Escola Superior de Direito Constitucional. Especialista em Direito civil e Processual Civil pelo Centro Universitário de Votuporanga. Advogado - SP. E-mail: anderson.grejanin@ig.com.br.

${ }^{3}$ Mestrando em Função Social do Direito: Acesso à Justiça pela Faculdade Autônoma de Direito de São Paulo - FADISP. Especialista em Direito Processual Civil pela Escola Paulista da Magistratura - EPM/SP, com capacitação para o ensino no magistério superior. Pós-graduado em Direito Privado pela Faculdade de Direito Damásio de Jesus - FDDJ/SP. Bacharel em Direito pela Faculdade de Direito "Laudo de Camargo", da Universidade de Ribeirão Preto/SP. Participou e concluiu os cursos "Contract Law: From Trust to Promise to Contract" e "Leaders of Learning - Liderança e Planejamento em Aprendizagem", na Harvard University/USA. Participou e concluiu o curso "European Union Law”, na Universidade Paris I Pantheón-Sorbonne/FR. Professor Titular da Faculdade Autônoma de Direito de São Paulo FADISP e de cursos preparatórios para concursos públicos e exame de Ordem. Membro da Comissão Permanente de Estudos de Processo Constitucional do Instituto dos Advogados de São Paulo - IASP. Assessor Jurídico do Tribunal de Justiça do Estado de São Paulo. Autor de livros e artigos jurídicos.
} 
RESUMO: A realidade dos conflitos levados à decisão do Poder Judiciário é uma questão muito relevante para o sistema democrático brasileiro e seu bom funcionamento é um ideal e também necessário para a paz social. A sua ausência levaria a uma crise no Poder Judiciário. As mudanças que estamos vivenciando com o novo CPC traz a ideia de melhoria e rapidez na prestação jurisdicional. Espera-se agilidade no julgamento dos processos. Diminuíram a quantidade de recursos, mas a ponto de resguardar importantes princípios constitucionais, como o contraditório e a ampla defesa, que neste quesito ganhou destaque, sem esquecer de uma adequada e razoável duração do processo. Para explicar algumas das realidades dos conflitos no judiciário, muitas injustiças que possam ter sido praticadas podem ser superadas e inclusive alteradas com o novo CPC. Solucionar os conflitos no Judiciário não é tarefa fácil, porém para evitar uma crise, uma aplicação mais efetiva da fundamentação das decisões judiciais, um aumento de responsabilidades para os magistrados frente às suas decisões, adequando-se essas à adimplência do contraditório e da ampla defesa e, por fim, propiciar a aplicação da celeridade, não fugindo da idéia da duração razoável do processo, deve ser observado com toda a cautela pelo Judiciário. Essas são algumas das possíveis soluções apresentadas que se espera do novo Código de Processo Civil.

Palavras-chave: conflitos; processo legal; contraditório; ampla defesa; motivação; coisa julgada.

\begin{abstract}
The reality of the conflicts brought to the judiciary decision is a very important issue for the Brazilian democratic system and its proper functioning is an ideal and also necessary for social peace. Their absence would lead to a crisis in the judiciary. The changes we are experiencing with the new CPC brings the idea of improvement and speed in judicial services. It is hoped agility trial processes. Decreased the amount of resources, but the point of protecting important constitutional principles, such as the contradictory and full defense, which in this aspect was highlighted, without forgetting an appropriate and
\end{abstract}


reasonable duration of the process. To explain some of the realities of conflicts in the judiciary, many injustices that may have been committed can be overcome and even changed with the new CPC. Resolve conflicts in the judiciary is not an easy task, but to avoid a crisis, a more effective application of the reasoning of judicial decisions, increased responsibilities to the front of judges its decisions, adapting these to the payments of the contradictory and full defense and finally support the implementation of speed, not running away from the reasonable duration of the process idea, it should be observed with all caution by the judiciary. These are some of the possible solutions presented what is expected of the new Civil Procedure Code.

Keywords: conflicts; legal process; contradictory; full defense; motivation; thing judged.

\section{INTRODUÇÃO}

A democracia, como realização de valores humanos e a concretização de direitos sociais, principalmente por trazer novas perspectivas para as pessoas que vivem o presente, rememorando o passado de lutas e de vitórias que alcançamos desde a Constituição Federal de 1988, prometendo muitas conquistas e vitórias ${ }^{4}$.

A realidade dos conflitos submetidos à apreciação do Poder Judiciário é situação preocupante diante dos grandes números de processos e da demora da solução das controvérsias, chega-se a falar em crise, ou muitas vezes ouvimos dizer, descrédito do Poder Judiciário.

O acesso à Justiça, uma garantia constitucional, por si só, não é suficiente capaz de responder de maneira efetiva e eficaz aos anseios de uma sociedade que está em constante transformação, na qual as relações a cada dia se tornam mais complexas,

\footnotetext{
${ }^{4}$ Essa análise, a partir de um passado iluminado, é relevante para que o futuro seja influenciado por um passado vitorioso e belo; isso é relevante para que a nossa sociedade não ande em um futuro nebuloso, fazendo vívidas as palavras de Tocqueville, que foi magistrado em 1827, de que o passado, quando não mais ilumina o futuro, deixa o espírito andando nas trevas. (TOCQUEVILLE, Alexis de. La démocratie em Amérique. Paris: Garnier: Flammarion, 1951, t. II, cap. VIII, p. 336).
} 
emergindo diariamente novas controvérsias que necessitam de solução. Nessa perspectiva, em função da crise que se estabeleceu no Poder Judiciário, é necessário que o próprio Judiciário procure novas formas para a solução dos litígios, uma vez que a sociedade espera uma prestação jurisdicional efetiva, célere e de qualidade.

Para tudo isso, analisaremos alguns pontos apresentados pelo Novo Código de Processo Civil de 2.015, instrumento que se espera resolver, em parte, os problemas relacionados ao Judiciário.

Portanto, o grande objetivo desta análise é poder conceber, a partir da observação de variados institutos, uma forma coesa de tentar solucionar as problemáticas que foram postas em decorrência da quantidade de conflitos submetidos ao Poder Judiciário, que faz com que os magistrados, em variados casos, decidissem de forma acelerada, sem o cuidado com a feitura da justiça.

\section{OS CONFLITOS NO PODER JUDICIÁRIO}

O mundo, hodiernamente, vivencia muitas ocorrências, relações aceleradas, contratações adesivas e uma constante busca desmedida de satisfação das demandas, consequência natural do buscado imediatismo e não mais a celeridade ${ }^{5}$.

A ousadia, a pressa, é uma realidade que as pessoas vivem atualmente, por viver não mais na modernidade, mas, sim, na pós-modernidade ${ }^{6}$.

\footnotetext{
${ }^{5}$ Deve-se tomar o devido cuidado para que as coisas não se acelerem por demais, visto que o direito deve seguir o seu tempo normal, sem uma aceleração exacerbada e desmotivada que prejudicaria e muito a natural preservação de um direito em sua essência máxima. (OST, François. O tempo do direito. Lisboa: Instituto Piaget, 1999, p. 39.)

${ }^{6}$ Nesse sentido, ver os seguintes autores: JAYME, Erik. Cours général de droit intenacional prive, In recueil des cours, Académie de droit intenacional. t, 251, 1997, p. 36-37; MARQUES, Claudia Lima. Contratos no código de defesa do consumidor: o novo regime das relações contratuais, 4. ed. rev., atual. e ampli., incluindo mais de 1.000 decisões jurisprudenciais. São Paulo, RT, 2002, p.155-175. LYOTARD, Jean-François. O pós-moderno. Rio de Janeiro: Olympio Editora, 1986. KUMAR, Krishan. Da sociedade pós-industrial à pós-moderna. Rio de Janiro: Jorge Zahar Editor, 1997. HARVEY, David. Condição pós-moderna. São Paulo: Edições Loyola, 1992. DELACAMPAGNE, C. História da Filosofia no Século XX. Rio de Janeiro: Jorge Zahar Editor, 1995. VATTIMO, Gianni. O Fim da Modernidade: niilismo e hermenêutica na cultura pós-moderna, Lisboa: Editorial Presença, 1987. FEATHERSTONE. Cultura de consumo e Pós-modernismo. São Paulo: Studio Nobel, SESC, 1995. CAMPBELL, C. The Romantic Ethic and the Spirit of Modern Consumerism. Oxford: Blackwell,1987. SANTOS, Boaventura de Souza. Pela Mão de Alice: O social e o político na pós-
} 
A sociedade brasileira passou por um crescimento que supera a velocidade de países europeus ou até de outros países que tenham também muito mais tempo de existência do que o Brasil.

Como observa Rui Portanova, a origem da celeridade ${ }^{7}$ da justiça, respeitar e observar a duração razoável do processo com o devido cuidado, pois pode acarretar muitos problemas e, por vezes, até infamar direitos que deveriam ser observados no transcurso de uma demanda.

Todo esse entusiasmo, o que começa a acontecer é a uma possível crise ${ }^{8}$, estendendo-se tanto para institutos não jurídicos como para os jurídicos, passando tanto

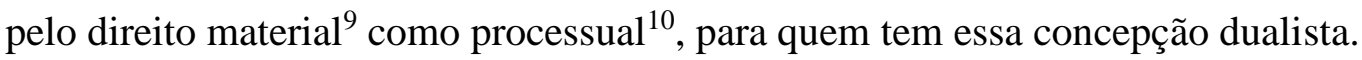

Miguel Reale se posiciona mostrando a existência da crise do Judiciário, arguindo que "são deveras alarmantes os dados sobre o aumento progressivo das causas julgadas e em curso perante a Suprema Corte, desde a promulgação da Constituição de 1988, elevando-se de 6.637 em 1989 para 40.823 em 1997”"11.

De fato, o Poder Judiciário ${ }^{12}$ sempre foi visto por seu cuidado com sua prestação de serviços para com os direitos dos cidadãos, de forma muito rígida. Uma crise $^{13}$ real, é muito perigosa, traz problemas e, sabidamente, poderá trazer muito mais,

modernidade. São Paulo: Cortez, 1997. BAUMAN, Zygmunt. Modernidade e Ambivalência. Rio de Janiro: Jorge Zahar Editor, 1999.

${ }^{7}$ Deve-se guardar a Idéia de processo célere, para que possa, dentro de um prazo razoável, atingir os fins para os que a ação foi proposta. Rememore-se que, segundo Rui Portanova, o princípio da celeridade derivado da economia processual. (In: PORTANOVA, Rui. Princípios do processo civil. $6^{\circ}$ ed., Porto Alegre: Livraria do Advogado, 2005, p. 171 e ss).

${ }^{8}$ A noção de crise que se apregoa aqui, antes de chegar à crise do Judiciário, é a crise do direito, que foi bem abordada por Shelma Kato (in: KATO, Shelma Lombardi de. A crise do direito e o compromisso da libertação in Direito e justiça: A função social do Judiciário - org. José Eduardo Faria, $3^{\circ}$ ed., São Paulo: Ática, 1997, p. 167 e ss).

${ }^{9}$ Para aclarar sobre o direito material, se for o caso, observar a obra de BEDAQUE, José Roberto dos Santos. Direito e processo: influência do direito material sobre o processo. $4^{\circ}$ ed., rev. e ampli., São Paulo: Malheiros, 2006, p. 54 e ss.

${ }^{10}$ Sobre a noção de direito processual civil recomenda-se SANTOS, Moacir Amaral. Primeiras linhas de direito processual civil. $7^{\circ}$ ed., São Paulo: Saraiva, 1980, p. 13 e ss.

${ }^{11}$ REALE, Miguel. Crise do capitalismo e crise do Estado. São Paulo: Editora SENAC, 2000, p. 107108).

${ }^{12}$ Um estudo interessante sobre o Judiciário foi elaborado por LABOULAYE, Edouard René Lefebvre de. Do Poder Judiciário in: O poder judiciário e a Constituição. Porto Alegre: coleção AJURIS 4, 1977, p. 11 ss.

${ }^{13}$ Para complementar a busca da melhor compreensão sobre a crise existente, averiguar SILVA, Ovídio A. Baptista da. In: Participação e processo. coord., Ada Pellegrini Grinover, São Paulo: RT, 1988, p. 98.

http://revistasapereaude.org/index.php/edicoes/ano-5-volume-3-outubro-2016

D.O.I: 10.20523/sapereaude-ano5-vol-3-pg-68-98 
podendo causar ainda mais prejuízos a toda a sociedade que depende das decisões dos magistrados para conseguir a efetividade de seus direitos e a solução de seus conflitos.

Não se pode atribuir o problema exclusivamente do Poder Judiciário, sendo de grande parte dos institutos - a exemplo da coisa julgada ${ }^{14}$ que será debatida - e de outras instituições como as universidades ${ }^{15}$ que possuem o curso de Direito poderão ter sua parcela de participação.

Essa concepção moderna que o Judiciário tem, decorrendo da nova visão que se tem do direito material e do processo $^{16}$, visão que busca, hoje, antes de tudo, a celeridade, deixando, por vezes, o direito mal protegido em decorrência da vontade insana de velocidade para términos das demandas que crescem a cada dia ${ }^{17}$.

O Judiciário, que não funcione bem, causa um prejuízo ainda maior para aquele que dele se socorreu. Tudo isso deve ser bem analisado, o Poder judiciário é essencial no Estado Democrático de direito “que impõe a participação efetiva $e$ operante do povo na coisa pública, participação que não se exaure, como veremos, na simples formações das instituições representativas" 18.

\footnotetext{
14 Esse instituto, que será tratado com maior vagar em seguida, tem sido considerado relativizáevel, mutável, não sendo mais absoluto, em tese, como antes, passando-se a uma idéia de que as relações que foram constituídas e decididas judicialmente de forma incorreta deveriam ser modificadas; isso se dá tanto no processo objetivo como subjetivo. Nesse sentido, ver NERY JÚNIOR, Nelson [et. all.]. Código de processo civil comentado e legislação extravagante. $10^{\circ}$ ed. rev., ampli. e atual., São Paulo: RT, 2007, p. 684-685.

15 Para essas peculiaridades das universidades que ofertam o curso de direito, resta a crítica em decorrência na não aplicação de forma adequada da modalidade correta de ensino, passando ao acadêmico aquele ensino meramente formal, um formalismo que se torna desnecessário. Resta a crítica, além desse ponto, da quantidade de faculdades de direito em nosso país, o que beira o absurdo. (SANTOS, Boaventura de Souza. Para uma revolução democrática da justiça. $2^{\circ}$ ed., São Paulo: Cortez, 2008 , p. 71-72).

${ }^{16}$ Sobre o direito processual civil, que para alguns não é considerado ciência, é considerado ciência por Ovídio A. Baptista da Silva, verbis: "O que há de surpreendente neste modo de compreender o direito é que apenas processo assumiu, para a doutrina, o caráter de ciência. O direito material conservou-se, para o pensamento moderno, um produto cultural e, como tal, sujeito às vicissitudes históricas e sociais". (SILVA, Ovídio A. Baptista da. Jurisdição, direito material e processo. Rio de Janeiro: Forense, 2008, p. 138.)

${ }^{17}$ Deve-se tomar o devido cuidado para que as coisas não se acelerem por demais, visto que o direito deve seguir o seu tempo normal, sem uma aceleração exacerbada e desmotivada que prejudicaria e muito a natural preservação de um direito em sua essência máxima. (OST, François. O tempo do direito. Lisboa: Instituto Piaget, 1999, p. 39.)

${ }^{18}$ SILVA, José Afonso da. Curso de direito constitucional positivo. 20. ed. São Paulo: Malheiros, 2001.
}

http://revistasapereaude.org/index.php/edicoes/ano-5-volume-3-outubro-2016

D.O.I: 10.20523/sapereaude-ano5-vol-3-pg-68-98 
O Ovídio A. Baptista da Silva ${ }^{19}$, o Poder Judiciário não funciona mal, funciona bem, levando em conta as limitações que foram impostas, por natural, em sua criação, algo que é muito natural. Esse poder foi criado para a solvência de $\operatorname{conflitos}^{20}$, gerando a consequente paz social ${ }^{21}$.

Antes de tudo, as críticas que são apontadas ao Judiciário devem ser analisadas de uma forma para que delas se possam retirar tudo aquilo que sirva positivamente, visando ao melhoramento das condições efetivas de prestação da tutela jurisdicional por parte do Poder Judiciário ${ }^{22}$.

${ }^{19}$ Ovídio A. Baptista da Silva, quando fala do Poder Judiciário, aduz que "Ele funciona segundo os princípios e pressupostos imaginados por aqueles que o conceberam. Um ponto que não preocupa aqueles que se angustiam com os atuais problemas da administração da justiça é saber se a celeridade processual fora, realmente, concebida como um objetivo desejado pelo sistema. Ou seja, ainda não se demonstrou que nosso sistema processual fora programado para andar rápido. Ao contrário, ao priorizar o valor segurança, inspirada em juízos de certeza, como uma imposição das filosofias liberais do Iluminismo, o sistema renunciou à busca de efetividade - que nossas circunstâncias identificam com celeridade -, capaz de atender à solicitação de nossa apressada civilização pós-moderna. O Poder Judiciário funciona satisfatoriamente bem, em nosso país. Os problemas da Justiça são estruturais. Não funcionais. Ele atende rigorosamente bem ao modelo que o concebeu. Nossa percepção, no entanto, não alcança os problemas estruturais que condicionam a atual situação vivida pelo Poder Judiciário - seja porque eles se tornaram, para nossa compreensão, "naturais", como o dia e a noite e o movimento dos astros -, seja por pareceremnos, de qualquer modo, como inalteráveis - a verdade é que a estrutura do sistema não é questionada, nem problematizada pelos que sofrem os danos de uma justiça que perdeu, até mesmo, a desejada funcionalidade. Pelo menos, os processualistas, que mais diretamente são atingidos por esse estado de coisas, não a questionam. Limitam-se a melhorar o seu funcionamento, como se o problema residisse em algum defeito funcional.

E, ainda, complementa: O problema, sem dúvida, não é funcional. Dentre outros muitos fatores desta ordem, ocorre-me o primeiro deles no próprio conceito e limites da jurisdição que praticamos como herança da Revolução Européia, desde suas origens medievais. O primeiro fator estrutural está na inabalável premissa redutora do conceito de jurisdição como simples declaração dos direitos, que é, por sua vez, o alicerce do procedimento ordinário e da interminável cadeia recursal. (SILVA, Ovídio A. Baptista da. Da função à estrutura - www.Baptistadasilva.com.br/artigos)

${ }^{20}$ Essa seria uma das formas de cumprir a função social do Poder Judiciário. Neste sentido, vejamos LOPES, José Reinaldo de Lima, in: FARIA, José Eduardo(coord.) [et. all]. Direito e justiça: A função social do judiciário, São Paulo: Ática, 1989, p. 123 e ss; Deve-se observar ainda as linhas traçadas por ROCCO, antigo professor da Universidade de Napoli, ao tratar da função jurisdicional. ROCCO, Ugo. Trattato di diritto processuale civile. V. I, $2^{\circ}$ ed., Torino: Topografia Sociale Torinese, 1966, p.46-48.

${ }^{21}$ (...) o que há de mais moderno já é alguma tendência a estabelecer um binômio de objetivos distribuídos entre o campo jurídico e social... ... entre outras tendências, preponderou a de que o escopo do processo reside na realização dos direitos subjetivos e (ou) confirmação da ordem jurídica, o objetivo cuja tarefa importante é a da manutenção da paz social da garantia da segurança jurídica. (DINAMARCO, Cândido Rangel. A Instrumentalidade do Processo. $9^{\circ}$ ed., São Paulo: Malheiros, 2001, p. 154).

${ }^{22}$ Ainda sobre a idéia de função social do Poder Judiciário, vejamos as palavras do jurista Álvaro Felipe Oxley da Rocha. ROCHA, Álvaro Felipe Oxley da. Sociologia do direito: A magistratura no espelho. São Leopoldo: Editora UNISINOS, 2002, p. 27. "O Judiciário tem ocupado freqüentemente espaços nos cenários políticos nacional e internacional em razão de sua atuação nos mais diversos setores, seja agindo como agente mantenedor da origem vigente, seja como transformador dessa mesma ordem, à medida que cresce a sua atuação modificadora das políticas de governo, impedindo ou dando nova direção às questões submetidas a seus agentes".

http://revistasapereaude.org/index.php/edicoes/ano-5-volume-3-outubro-2016

D.O.I: 10.20523/sapereaude-ano5-vol-3-pg-68-98 
Claro que a crise, que se desenvolveu com o passar do tempo, veio causando enormes prejuízos; isso não se discute, mas o que, de fato, se discute o motivo da existência da crise. Na verdade, não devem existir questionamentos a respeito da eventual existência ou não da crise, pois ela existe, mas deve-se pensar o motivo de sua existência e de sua persistente confirmação.

Essas questões nos levaram a outro universo de discussão, onde veremos um Poder Judiciário abarrotado de trabalho, acumulando, a cada dia, mais processos, em seus respectivos cartórios, afetando-se o magistrado da condição de poder bem, e calmamente, decidir.

Sabe-se que a quantidade de processos que existem hoje torna o exercício da jurisdição ${ }^{23}$ cada vez mais complexa e difícil, pois a quantidade de ações que existem exige do Judiciário, de forma rápida ${ }^{24}$, a solucionar o litígio, ainda que de forma insatisfatória.

Essa é uma das situações mais complexas que pode ser superada, mas que não será fácil de ser vencida pela hodierna condição do Poder Judiciário que conta com um quadro diminuto e insuficiente de servidores para dar conta de toda demanda que bate às portas do Judiciário. Isso pode e deve ser alterado, mas, na atual situação econômica de nosso país, demonstra ser algo complexo e muito difícil de ser realizar.

Além dessa situação gravosa, outra de grande magnitude se impõe, qual seja a da ausência de manifestação do Poder Legislativo, que deveria elaborar leis ${ }^{25}$ que regulassem a vida em sociedade, por ser essa a função social deste Poder, fato esse que não é cumprido ${ }^{26}$. E esse não cumprimento gera uma série de celeumas das quais precisamos analisar e tomar a devida ciência, para buscar a solução.

\footnotetext{
${ }^{23}$ Sobre o que seja jurisdição, importante é observar MARINONI, Luiz Guilherme. MITIDIERO, Daniel. Código de direito processual civil comentado. São Paulo: RT, 2008, p. 95 e ss.

${ }^{24}$ A celeridade deve ser empregada com moderação, visando a não prejudicar o direito efetivamente constituído e pelo qual se instala o litígio judicial, pois nem sempre a decisão rápida terá o condão de ser adequada ou, ainda, correta. Assim, a celeridade, por mais importante que seja, tem limites que devem ser observados. SANTOS, Boaventura de Souza. Para uma revolução democrática da justiça. $2^{\circ}$ ed., São Paulo: Cortez, 2008, p. 27.

${ }^{25}$ Kelsen constrói a idéia de que lei é direito e que por essa razão deveríamos estar submissos a lei, vide: KELSEN, Hans. Teoria pura do direito. $4^{\circ}$ Ed., São Paulo: Martins Fontes, 1994, p. 33 e ss.

${ }^{26}$ Idem., p. 21. Com a efetiva omissão do Poder Legislativo em relação a várias questões, o Poder Judiciário toma a frente na solução dos conflitos que se formam, a partir da ausência de manifestação do
} 
Os cidadãos que não têm as suas situações solucionadas pelo Poder Legislativo, que deveria legislar sobre uma determinada matéria, vão buscar socorro aos seus anseios junto ao Poder Judiciário, o que, por mais uma vez, faz com que o dito Poder precise gastar seu tempo para solver essas ocorrências perniciosas em decorrência da omissão do Legislativo, inflando mais a estrutura do Poder Judiciário.

Isso não deveria ocorrer, o Legislativo deveria cumprir o seu papel de legislar e regulamentar o comportamento da sociedade de uma forma geral, o que por si só, além de cumprir a função social deste Poder, ajudaria o Judiciário a não ficar, cada vez mais sobrecarregado. Mas isso não ocorre, pois a omissão do Legislativo persiste e coloca o Judiciário em situação desprestigiada ${ }^{27}$ junto à sociedade, que acredita que o problema é deste poder, quando, em verdade, essa demanda, geradora de morosidade ${ }^{28}$, é decorrência da inação do nosso Congresso Nacional.

Vemos uma grande problemática com tudo isso, pois o Judiciário acaba por fazer função que não é sua, a de legislar de forma indireta, fazendo nascer a figura do ativismo judicial ${ }^{29}$, ou ainda, da judicialização da política. O Judiciário passa a fazer as vezes de "legislador", quando sabe ser, efetivamente, por delegação constitucional, julgador. Aqui surge um problema, pois, se esse Poder foi concebido para julgar, não deveria legislar, quer por não ter, em tese, condição e preparação para tanto, quer por haver uma separação dos poderes ${ }^{30}$, que limita a ação de cada um dos Poderes, visando

Legislativo, fazendo com que o Judiciário passe a solver as dúvidas existentes e que foram deixadas por aquele poder. Diga-se, ainda, que essa manifestação do Judiciário tem sido latente tanto em questões do Legislativo como também do Executivo.

${ }^{27}$ O Poder Judiciário passa a ser mais desvalorizado pela sociedade a cada dia, seja por ser, para muitos, como a mera boca da lei, como também por ser um Poder moroso. Essa morosidade que advém da má prática do Poder Legislativo deve ser cessada para que o Judiciário possa novamente ganhar força e voltar a ser o Poder respeitado que sempre foi. Idem., p. 11.

${ }^{28}$ Sobre o tema da morosidade do Judiciário, caso seja necessário o esclarecimento, vide: ROCHA, Álvaro Felipe Oxley da. Sociologia do direito: A magistratura no espelho. São Leopoldo: Editora UNISINOS, 2002, p. 119 e ss.

${ }^{29}$ Idem., p. 23.

${ }^{30}$ MONTESQUIEU, Charles de Secondat, Baron de. Do Espírito das Leis. São Paulo: Saraiva, 2000, p. 167-168. Também devemos observar Duverger, Maurice. Constitutions et documents politiques. Paris: PUF, 1974, p. 10. "Toute société dans laquelle la garantie dês droits n'est pás assurée, ni la séparation des pouvoirs déterminée, n'a point Constitution". Por tudo isso a separação dos poderes é relevantíssima, pois é a base inicial para um Estado forte. Ademais, conforme acentua o jurista português NUNO PIÇARRA, esta doutrina da separação de poderes remonta à Grécia e Roma antiga. (PIÇARRA, Nuno. A Separação dos Poderes como doutrina e Princípio Constitucional - Um contributo para o estudo das suas origens e evolução. Coimbra: Coimbra Editora, 1989, p. 31.)

O autor lusitano identifica as origens da idéia da separação dos poderes no conceito de constituição mista de ARISTÓTELES em sua obra Política, segundo o qual: “(...) constituição mista, para Aristóteles, será 
à harmonia destes para que a sociedade ganhe maior efetividade com as atribuições partilhadas. Ressalte-se a exceção da teoria dos freios e contrapesos, em que cada um dos Poderes exerce um pouco das funções dos demais, mas de forma moderada e pontuada.

Deve-se agregar a essas problemáticas, ressaltadas anteriormente, o costume litigante dos brasileiros que se acentua mais a cada dia. Nossa sociedade se mostra mais demandante e questionadora a cada dia e isso é bom até certo ponto, especificamente até onde se possa garantir a proteção de direitos e exigir o cumprimento de contratos, por exemplo. Contudo, quando isso descamba para a idéia da simples e desmotivada demanda, a problemática surge. O que se tem visto, com muita frequência, é o crescente costume de demandar por qualquer coisa, fazendo o uso do meio processual e da máquina do Judiciário para discutir o óbvio, que poderia ser solucionado pela simples composição, tendo como exemplo a justiça restaurativa ${ }^{31}$.

Esse acontecimento também tem sido um forte fator de acúmulo de processos junto ao Judiciário, o que faz com que a situação fique cada vez mais complexa, dotando de maior morosidade ${ }^{32}$ as demanda judiciais, prejudicando a obtenção dos direitos que são, por muitas das vezes, intrínsecos e subjetivos, que seriam de fácil e rápida proteção, caso o volume de processos fosse menor, tornando-se, no entanto, uma discussão longa em decorrência de toda essa exacerbação do direito de petição.

Várias consequências muito perniciosas surgem dessa crise que vivencia o Poder Judiciário ${ }^{33}$. Uma delas é bem esposada por Ovídio A. Baptista da Silva,

\footnotetext{
aquela em que os vários grupos ou classes sociais participam do exercício do poder político, ou aquela em que o exercício da soberania ou o governo, em vez de estar nas mãos de uma única parte constitutiva da sociedade, é comum a todas. Contrapõem-se-lhe, portanto, as constituições puras em que apenas um grupo ou classe social detém o poder político.”( Idem., p. 33.)

${ }^{31}$ A justiça restaurativa, que hodiernamente é estudada, é interessante, pois parte da idéia de composição da lide, de solução da lide sem o transcurso natural da lide, que é, por sinal, muito delongado. Sobre justiça restaurativa deve ser miradas as lições que o eminente jurista SANTOS, Boaventura de Souza. Para uma revolução democrática da justiça. $2^{\circ}$ ed., São Paulo: Cortez, 2008, p. 58.

${ }^{32}$ A necessidade de pensar algo que possa agir contra a morosidade ou lentidão dos processos, algo que está sendo perceptível, sobre a busca de soluções veja OST, François. O tempo do direito. Trad. Élcio ernandes, Bauru: Edusc, 2005, p. 17.

33 Outra grande problemática se dá também ente o Judiciário e a mídia, em que a problemática é de altíssima complexidade. Para melhor compreender vide: ROCHA, Álvaro Felipe Oxley da. Sociologia do direito: A magistratura no espelho. São Leopoldo: Editora UNISINOS, 2002, p. 65 e ss.
} 
quando fala da "justiça pasteurizada" 34, que seria nada mais do que uma prestação da tutela jurisdicional seriada e despreocupada com o caso em concreto, em que o que vale é decidir de forma rápida e se livrar o quanto antes daquele processo ${ }^{35}$, que é visto como mais um dos infindos fardos que o Judiciário carrega.

A "justiça pasteurizada" é maléfica, pois, efetivamente, limita os direitos dos cidadãos, a partir de uma análise descuidada e desmedida que é feita pelo Poder Judiciário, restringindo, não somente os direitos que são pretendidos, mas também a própria condição de pensar do Poder Judiciário, que tem total liberdade intelectual para bem julgar ${ }^{36}$ e fundamentar ${ }^{37}$ suas decisões. Devemos buscar nos afastar dessa ocorrência que se mostrou, desde logo, terrível e maléfica, por colocar o cidadão em situação inconcebível e o próprio Judiciário em posição de desprestígio total.

Outro grande obstáculo que deve ser superado, e decorre de todas as práticas anteriormente referidas, é ocorrência dos "votos prontos" ${ }^{38}$ que são ofertados pelo próprio Poder Judiciário que, antes de tudo, deveria prezar por seus julgados e

\footnotetext{
34 "Para quem visualiza o sistema pela perspectiva de um operador forense, seu funcionamento não se mostra apenas insatisfatório. Mostra-se assustador. Como era de supor, a extraordinária litigiosidade que caracteriza nosso tempo, obriga os magistrados a padronizarem suas decisões, praticando - com maior ou menor vocação para o normativismo abstrato - uma jurisdição "pasteurizada", sem compromisso com o "caso"".

O autor ainda continuar: "De qualquer modo, esta prática estimula o arbítrio, porque os julgadores, por várias razões e circunstâncias, julgam-se dispensados de fundamentar adequadamente as sentenças. Quem declara - apenas descompromissadamente declara -, não tem o que justificar. Não está obrigado a fundamentar a possível injustiça declarada, pela qual o declarante não é responsável".( DA SILVA, Ovídio A. Baptista. Da função à estrutura - www.Baptistadasilva.com.br/artigos).

${ }^{35}$ Sobre a idéia de formalismo no processo civil, deve-se observar a obra do jurista Carlos Alberto Alvaro de Oliveira, que refere a importância do formalismo, na medida adequada, sendo este formalismo, para ser aceitável, valorativo e não um formalismo despropositado que afoga o Poder Judiciário e prejudica a sistemática processual. (OLIVEIRA, Carlos Alberto Alvaro. Do formalismo no processo civil. $2^{\circ}$ ed. rev. e ampli., São Paulo: Saraiva, 2003.)

36 No sentido de observar o bem julgar propiciador da construção da democracia, vide GARAPON, Antonie. Bem julgar: ensaio sobre o ritual judiciário. Lisboa: Instituto Piaget, 1997, p.327.

${ }^{37} \mathrm{~A}$ fundamentação que é requisito indispensável às decisões judicial, em principal à sentença, por ser a forma de convencer as partes da decisão que foi tomada, sendo esse dever de fundamentar do Judiciário uma garantia para o cidadão. Para compreender melhor a idéia utilizada para o princípio da fundamentação, que, para alguns, é a mesma coisa que motivação, ver NERY JÚNIOR, Nelson. Princípios do processo civil na constituição federal. $7^{\circ}$ ed. rev. atual., São Paulo: RT, 2002, p. 180 e ss. 38 "A avalanche de recursos provoca uma extraordinária violência contra a Constituição. A causa é julgada privadamente. O julgamento não é público. Mesmo assim, ele se dá por unanimidade, sem que os demais componentes do colegiado proclamem publicamente seus votos. Para o público que assiste à sessão de julgamento, os votos dos demais magistrados é um segredo, embora se fique sabendo depois que os votos resumiram-se ao tradicional "de acordo com o relator". É de supor que tenham votado também na véspera. As comunicações eletrônicas permitem que o julgamento colegiado se dê antes da abertura da sessão pública. Nesta, ouve-se apenas a voz do Presidente a proclamar o resultado". (DA SILVA, Ovídio A. Baptista. Da função à estrutura - www.Baptistadasilva.com.br/artigos).
} 
buscar torná-los cada vez mais fortes e respeitáveis, afronta, além de toda a boa prestação jurisdicional esperada do Judiciário, os direitos e a possibilidade jurídica de vitória da parte que recorre, ou, ainda, do recorrente, pois os votos que são preparados, antes mesmo do momento do julgamento do recurso, serão simplesmente lidos no dia marcado para o julgamento.

Sabe-se que o volume recursal é soberbo e que isso dificulta, e muito, a atividade dos julgadores, pois, além de julgarem os feitos recursais, devem observar os critérios de admissibilidade dos recursos, que têm a função de filtrar a possibilidade recursal, visando a desafogar o Judiciário. Não se critica os critérios utilizados como requisitos de admissibilidade, pois estes são extremamente necessários, mas, sim, a má utilização desses critérios e, por vezes, inclusive, em votos prontos, que impossibilitam o conhecimento do que realmente se busca discutir.

Essa problemática também é decorrência de todo o acúmulo de trabalho que se agregou ao Poder Judiciário, fruto de tudo aquilo que discutimos sobre o Legislativo e as demais modalidades de surgimento de demandas que abarrotam o Judiciário.

Agrega-se, ademais, outra questão que se discute bastante, a fundamentação das decisões judiciais, pois, como sabemos, essa necessidade de fundamentação é imprescindível, dotando as decisões judiciais de força e de justificação.

As decisões judiciais devem ser fundamentadas ${ }^{39}$ demonstrando os argumentos jurígenos que foram utilizados pelo julgador, para que, assim, a parte possa se convencer da decisão, concordando ou não com ela. A questão fica ainda mais complexa depois que se percebe a existência de uma fundamentação incompleta, por mais que respeitando os critérios formais, como tem-se dado, pois a decisão tem uma fundamentação, em tese, mas isso não é o bastante, já que uma fundamentação deve ser

\footnotetext{
39 Bem assevera o art. 93, IX da Carta Política, verbis: "IX todos os julgamentos dos órgãos do Poder Judiciário serão públicos, e fundamentadas todas as decisões, sob pena de nulidade, podendo a lei limitar a presença, em determinados atos, às próprias partes e a seus advogados, ou somente a estes, em casos nos quais a preservação do direito à intimidade do interessado no sigilo não prejudique o interesse público à informação".
} 
a clara explicação do Judiciário para o cidadão de que terá ou não o direito por tal razão jurídica e/ou fática.

Surge, para a nossa realidade processual caótica, crítica relevante para a mudança dessa realidade anacrônica, feita por Ovídio A. Baptista da Silva, baseada nas lições de Carnelutti e Chiovenda, sendo relevante um movimento de decisão interna do julgador, antes mesmo de decidir a causa e seus pedidos, pois, se o magistrado não se decidir, antes de tudo, menor será a sua condição de decidir a problemática judicial criada e posta à sua frente ${ }^{40}$.

É disso que se fala, de uma explicação efetiva dos motivos decisórios e não de um amontoado de palavras que não se servem a explicar qual tese adotada, ou, ainda, qual a realidade fenomênica considerada. Por tudo isso, antes de qualquer manifestação judicial, o julgador deve decidir a sua posição em relação a lide por meio das provas acostadas ao processo, formando essa convicção pelo livre convencimento motivado $^{41}$. Além disso, outra coisa se tem percebido e, cada vez, mais nas decisões judiciais é a decisão que fundamenta somente uma parte da questão, dizendo que uma das partes obteve o direito com base em uma determinada concepção jurídica, não explicando ao sucumbente o motivo da sua derrota. Isso é relevante, pois a fundamentação deve se dar no sentido de explicar ao vencedor o motivo de seu êxito e, ao perdedor, as razões de sua derrota. Tudo isso seria também uma forma de reduzir, pelo menos em tese, a incidência recursal, já que se convencida for a parte dos motivos de sua vitória ou derrota, dificilmente, virá a recorrer desta decisão ou, pelo menos, causaria severa dúvida na busca da utilização do rol taxativo dos recursos.

Por fim, outro grande ponto decorrente de toda a problemática instalada é o enfraquecimento das decisões de $1^{\circ}$ grau, pela simples existência da possibilidade

\footnotetext{
40 "Daí porque somente haverá autêntica decisão jurisdicional quando o sistema jurídico reconheça a seus juízes algum grau de discricionariedade, para que ele possa, como dissera Carnelutti, antes de decidir, "decidir-se". A discricionariedade, como todos sabem, está institucionalmente ausente na jurisdição apenas declaratória. Nossos juízes não decidem apenas julgam. Decidir é ato volitivo, julgar é ato intelectivo. Qualquer calouro em curso psicologia conhece essa distinção elementar. Decisão é ato de vontade, de que nossos magistrados estão institucionalmente privados, como dissera Chiovenda. Sim, pode haver "novas interpretações da lei velha", não porém "como mister do juiz" (DA SILVA, Ovídio A. Baptista. Da função à estrutura - www.Baptistadasilva.com.br/artigos).

41 Vide MARINONI, Luiz Guilherme. MITIDIERO, Daniel. Código de direito processual civil comentado. São Paulo: RT, 2008, p. 177-178; THEODORO JÚNIOR, Humberto. Curso de Direito Processual Civil: Teoria do Direito Processual Civil e o Processo de Conhecimento. $39^{\circ}$ ed., Rio de Janeiro: Forense, 2003, v.1, p.38.
} 
recursal livre. Tem-se percebido uma desvalorização natural da decisão do juízo de instância inicial, que foi justamente aquele que teve contato com a prova, que ouviu o depoimento pessoal, que fez a inspeção judicial ou que produziu e colheu, de forma pessoal, as provas que fazem parte do processo. Esse magistrado deveria ter maior valorização tanto de sua atividade, de uma forma geral, como também de suas decisões, fazendo com que esse juiz fosse mais exigido, gerando um grau de responsabilidade maior por parte do juiz, não se limitando apenas a decidir as demandas. Compreendemos que essa ocorrência é uma das problemáticas da crise vivenciada pelo Poder Judiciário, pois o juiz de $1^{\circ}$ grau tem sido desvalorizado e desmotivado por toda a exagerada possibilidade recursal decorrente de sua decisão ${ }^{42}$.

Assim, não há como falar da inexistência da crise do Judiciário, pois essa é inerente, mas deve-se falar sim em superação dessa crise que se implantou e que vem causando infindos prejuízos tanto para a sociedade que aguarda muito do Poder Judiciário como também dos próprios membros deste Poder, que foram preparados para serem, antes de tudo, juristas pensantes e que constroem a sociedade e lutam contra as desigualdades, buscando sempre a adimplência da Constituição Federal e dos direitos e garantias fundamentais expansíveis a todos os cidadãos e não meros repetidores da mesmice ou, ainda, a boca da lei. ${ }^{43}$

\section{DO DEVIDO PROCESSO LEGAL}

No Brasil, a inclusão definitiva e expressa da garantia do "due processo of law" veio somente com a Constituição Federal de 1988, que em seu art. 5 , LIV, prevê, que "ninguém será privado da liberdade ou de seus bem sem o devido processo

\footnotetext{
${ }^{42} \mathrm{O}$ posicionamento de Ovídio sobre o tema é o seguinte: "O risco de comprometerem-se com a causa, antes da sentença final, é um fator sistemático (conseqüentemente estrutural) predisposto para manter o juiz em sua natural passividade. O sistema recursal é o instrumento que vigia a observância desta imposição. É natural, portanto, que os juízes procurem não se envolver com as questões de mérito da causa, antes de poderem proclamá-la no momento adequado. Temos um magistrado concebido para manter-se passivamente neutro, durante o curso da relação processual".

$\mathrm{O}$ autor, ainda, complementa sua argumentação arguindo que "O trágico produto do Racionalismo - que se esmerou em tornar o Direito uma "ciência", segundo o modelo matemático - foi dar-nos um "juiz irresponsável", metódica e institucionalmente irresponsável, cuja missão está limitada a declarar as injustiças cometidas pelo legislador". (DA SILVA, Ovídio A. Baptista. Da função à estrutura www.Baptistadasilva.com.br/artigos).

${ }^{43}$ CHIOVENDA, Giuseppe. Principios del derecho procesal. Madri: Reus, s/d, p. 365.
}

http://revistasapereaude.org/index.php/edicoes/ano-5-volume-3-outubro-2016 
legal”, sendo esta ordem complementada pelo inciso LV do mesmo artigo: "os litigantes em processo judicial ou administrativo, e aos acusados em geral são assegurados o contraditório e a ampla defesa, com os meios e recursos a ela inerentes".

Somente com a oitava Constituição, trouxe a seu ordenamento jurídico este princípio conquistado pelo barões ingleses em 1215, do qual derivam para o processo civil, penal e administrativo uma série de outras garantias. No entanto, embora de maneira não expressa, as Cartas Constitucionais brasileiras trouxeram estipulações que garantiam aos cidadãos alguns direitos que influenciaram grandes debates jurídicos entre aqueles que desacreditavam completamente na presença da garantia em nosso ordenamento jurídico e os que pretendiam enxerga-lo onde fosse possível. Passaremos a comentar esta ausência sentida dividindo as Constituições anteriores à atual em duas partes: a primeira tratando exclusivamente da Constituição de 1824, a primeira a omitirse, e a segunda compreendendo o período entre a Constituição Republicana e a Emenda Constitucional n.01, de $1969^{44}$.

O devido processo legal foi concebido como uma garantia de feições apenas processuais, como princípio que viria a assegurar que a privação da liberdade e da propriedade somente seriam possíveis através de um processo regular. Como esse aspecto foi que o due processo f law manteve-se vivo na Inglaterra, nas Constituições das Colônias Inglesas na América e, posteriormente, nas Emendas 5 e 14 da Constituição dos Estados Unidos. Inicialmente dirigida à jurisdição penal foi estendida, em seguida, à jurisdição civil e, recentemente, aos procedimentos administrativos.

O devido processo legal, aponta Nelson Nery Júnior, é caracterizado pelo trinômio vida-liberdade-propriedade, ou seja, "tem-se o direito de tutela àqueles bens da vida em seu sentido mais amplo e genérico. Tudo o que disser respeito à tutela da vida, liberdade ou propriedade está sob a proteção da due process clause ${ }^{45}$ ". Por isso a Corte Americana já entendeu que faz parte do conceito de liberdade: a liberdade de imprensa, de opinião e - mais profundamente - a privacidade. A mesma Corte decidiu pela inconstitucionalidade da lei estadual que proibia o ensino em outra língua que não o inglês, estendendo a proibição às escolas públicas e privadas (Meyer x Nebraska, 1923);

\footnotetext{
${ }^{44}$ Sobre o devido processo na Constituição Federal de 1988 cuidaremos no capítulo seguinte.

${ }^{45}$ NERY JÚNIOR, Nelson. Princípios do processo na Constituição Federal: processo civil, penal e administrativo. 10 ed. rev., ampl. e atual. São Paulo: Revista dos Tribunais, 2010
} 
também invalidou lei estadual que exigia que crianças normais entre 8 e 16 anos somente fossem matriculadas em escolas públicas e proibia as escolas privadas e paroquias de aceita-las, entendendo pela irrazoabilidade da lei, que interferia na liberdade dos pais e na propriedade das escolas (Pierce x Society os Sisters, 1925).

Neste passo, a concepção da garantia em exame não pode ser formada em termos exclusivamente processuais, como pode parecer à primeira vista e como foi apresentada até este ponto do trabalho - incluídas as ponderações acerca de sua evolução histórica, a adoção no direito estrangeiro e no direito brasileiro. Ao contrário, possui sentido genérico e biparte-se em substantive due process e em procedural due process, "para indicar a incidência do princípio em seu aspecto substancial, vale dizer, atuando no que respeita ao direito material, e, de outro lado, a tutela naqueles direitos por meio do processo judicial ou administrativo.

A constituição Federal de 1988 foi responsável pela inauguração de uma nova etapa para o desenvolvimento do devido processo legal em nosso direito, principalmente pelo ineditismo de sua consagração expressa e, mais importante, pela extensão da garantia aos litigantes em processo civil e trabalhista, aos acusados em processo penal e interessados em processo administrativo. Consequentemente, é dever reconhecermos a existência de uma base principiológica derivada do due processo of law, a determinar seus limites e alcance na esfera processual. Porém, observações deste aspecto serão tratadas no próximo capítulo. Cuidaremos, por hora, de alinhavar o sentido material do princípio.

A necessidade de intervenção judicial nas atividades estatais principalmente legislativa - fez nascer uma bipartição ideológica a pairar sobre o devido processo legal, principalmente no direito norte- americano através dos julgados da Suprema Corte. Entendeu-se que não somente em sentido processual deveria o princípio garantir o trinômio vida-liberdade-propriedade, porque de tão amplo deveria cuidar de corrigir eventuais abusos do poder soberano ao legislar. Em outras palavras, criou-se a idéia de que o devido processo legal - concebido como clausula anti-arbitrio - seria também responsável por vincular a produção legislativa à idéia de razoabilidade ou proporcionalidade. Baseada no espírito que norteou a Magna Carta de 1215, diz a doutrina: uma lei não pode ser considerada uma law of the land, nos termos desejados 
pelo due processo of law, se incorrer na falta de razoabilidade, ou seja, quando for $\operatorname{arbitrária~}^{46}$.

A idéias de governo dos juízes, como os tribunais assumindo a função de sensores da vida social, política e econômica da nação norte-americana, fez com que a visão unicamente processualista do devido processo legal retrata-se a "entrada em cena do Judiciário como árbitro autorizado e final das relações do governo com a sociedade civil, revelando o seu papel de protagonista e igualmente 'substantivo' no seio das instituições governativas.

\section{DO CONTRADITÓRIO E A AMPLA DEFESA}

A Constituição Federal de 1988 no título que trata dos direitos e garantias individuais, inseriu o princípio do contraditório e da ampla defesa, portanto princípios constitucionais.

O novo CPC deu maior atenção ao princípio do contraditório, sendo este princípio constitucional muito mais valorizado no novo diploma. Os dispositivos que abordam o contraditório em suas diversas formas, podem-se destacar os artigos $7^{\circ}, 9^{\circ} \mathrm{e}$ 10, do CPC, todos previstos no capítulo das normas fundamentais do processo civil.

Segundo o art. $7^{\circ}$ do $\mathrm{CPC}$ "é assegurada às partes paridade de tratamento em relação ao exercício de direitos e faculdades processuais, aos meios de defesa, aos ônus, aos deveres e à aplicação de sanções processuais, competindo ao juiz zelar pelo efetivo contraditório”.

$\mathrm{O}$ art. $9^{\circ}$ do CPC determina que "não se proferirá decisão contra uma das partes sem que ela seja previamente ouvida”, com o que se proíbe decisão-surpresa do juiz.

E o art. 10 diz o seguinte: "O juiz não pode decidir, em grau algum de jurisdição, com base em fundamento a respeito do qual não se tenha dado às partes

\footnotetext{
46 CASTRO, Carlos Roberto de Siqueira. O devido processo legal e a razoabilidade das leis na nova Constituição do Brasil. Rio de Janeiro: Forense, 1989.
} 
oportunidade de se manifestar, ainda que se trate de matéria sobre a qual deva decidir de ofício".

Referente ao artigo 10, a Escola Nacional de Formação e Aperfeiçoamento de Magistrado (ENFAM) divulgou alguns dispositivos possuem pertinência direta com o art. 10 do novo CPC, como: "1- Entende-se por "fundamento" referido no art. 10 do $\mathrm{CPC} / 2015$ o substrato fático que orienta o pedido, e não o enquadramento jurídico atribuído pelas partes"; "2 - Não ofende a regra do contraditório do art. 10 do CPC/2015, o pronunciamento jurisdicional que invoca princípio, quando a regra jurídica aplicada já debatida no curso do processo é emanação daquele princípio"; “3 - É desnecessário ouvir as partes quando a manifestação não puder influenciar na solução da causa"; "4 - Na declaração de incompetência absoluta não se aplica o disposto no art. 10, parte final, do CPC/2015"; "5 - Não viola o art. 10 do CPC/2015 a decisão com base em elementos de fato documentados nos autos sob o contraditório"; "6 - Não constitui julgamento surpresa o lastreado em fundamentos jurídicos, ainda que diversos dos apresentados pelas partes, desde que embasados em provas submetidas ao contraditório”;(...) “55) Às hipóteses de rejeição liminar a que se referem os arts. 525, § $5^{\circ}, 535, \S 2^{\circ}$, e 917 do CPC/2015 (excesso de execução) não se aplicam os arts. $9^{\circ}$ e 10 desse código" 47 .

\section{A MOTIVAÇÃO DAS DECISÕES JUDICIAIS}

É tão importante a fundamentação das decisões judiciais que o novo CPC, logo no artigo 11, traz que "todos os julgamento serão públicos, e fundamentadas todas as suas decisões, sob pena nulidade”.

Apesar do novo CPC começar exigindo a fundamentação de todas as suas decisões, a Lei 13.256/2016 abrandou tal exigência de obrigatoriedade de fundamentação de todos os pontos da sentença, bastando ao juiz concentrar-se sobre os que julgarem relevantes (art. $\left.1.038, \S 3^{\circ}\right)$.

\footnotetext{
${ }^{47}$ Disponível em: http://www.enfam.jus.br/2015/09/enfam-divulga-62-enunciados-sobre-a-aplicacao-donovo-cpc/ Acesso em 01/09/2015.
} 
A obrigatoriedade de fundamentação das decisões judiciais erigida à condição de princípio constitucional, mediante o art. 93, inc. IX, da CF de 1988, tornou mais complexo o problema da motivação, o qual havia sido comodamente incorporado no senso comum teórico dos processualistas, como decorrência do Estado Democrático de Direito.

É questão de natureza lógica que uma decisão tem que ser coerente com o pedido, sob pena de nulidade, independente de disposição normativa, do mesmo modo que se exige a coerência lógica entre diferentes escalões normativos, sob pena de nulidade por inconstitucionalidade ou ilegalidade. Como diz Arruda Alvim, "é exatamente no instante em que é proferida a sentença que tal atividade lógica assume o momento fundamental de sua aplicação, no campo processo ${ }^{48}$

A obrigatoriedade de fundamentação das decisões judiciais ${ }^{49}$, erigida à condição de princípio constitucional, mediante o art. 93, inc. IX, da Constituição Federal de 1988, tornou mais complexo o problema da motivação, o qual já havia sido comodamente incorporado no senso comum teórico dos processualistas, como decorrência do Estado Democrático de Direito. Chaim Perelman o remonta à Revolução Francesa, com o objetivo de submeter os juízes demasiado independentes à vontade da nação, isto é, à do legislador que a encarna. Enfatiza ainda que o Tribunal de Cassação foi instaurado para zelar no sentido de que as Cortes e os Tribunais, encarregados de aplicar a lei, expressão da vontade nacional, não usassem de seu poder para violar a Lei. A motivação, tal como concebida pelo Constituinte, deveria garantir ao Poder Legislativo a obediência incondicional dos Juízes à lei ${ }^{50}$.

Esta maior complexidade é enfatizada por Michele Taruffo, que salienta as incertezas na formulação doutrinária do problema, em consequência da crise da

\footnotetext{
${ }^{48}$ ARRUDA ALVIM. Manual... cit. p.

49 Teresa Arruda Alvim WAMBIER, analisando a ausência de fundamentação como vício da sentença, afirma que "a este respeito há, praticamente, unanimidade na jurisprudência”. (Nulidades ..., cit., p.320).

${ }^{50}$ PERELMAN, Chaim. La Motivation Des Décisions de Justice, Essai de Synthèse. In: PERELMAN, Ch; FORIERS, P. La motivation des decisions de justice. Bruzelles: Établissementes Émile Bruylant. Société Anonyme D' Editions Juridiques et Scientifiques, 1978. (Publications Du Centre National de Recherches de Logique (Section Juridique). Etudes publiées par Ch. Perelman et P. Foriers). P. 415-426.
} 
doutrina da subsunção jurídica, qual seja, a concepção silogística da sentença, e das influências sociológico-políticas nos julgados ${ }^{51}$.

Essa amplitude do instituto, se por um lado enriqueceu a dogmática com novos argumentos de caráter estritamente jurídico, por outro introduziu num instituto processual as discussões filosóficas que já cercavam os temas de direito constitucional acerca dos fundamentos dos princípios gerais e da própria natureza do fundamento.

O que na verdade ocorreu, desde a Constituição de 1988, foi o alinhamento do pensamento jurídico pátrio com o que já se tornara recorrente na doutrina estrangeira. $\mathrm{O}$ fundamento das decisões judiciais deixará de ser uma questão dogmática para tornar-se um problema de teoria geral do direito ${ }^{52}$.

Acresce que a decisão não se restringe aos despachos, sentenças e acórdãos, ela não é somente judicial, mas jurídica, pois o direito como experiência se manifesta como norma ou decisão, e está, segundo a importância do órgão que decide, transforma-se em norma. Ou seja, o decisum judicial é o direito in concreto.

Mas essa questão é sobretudo de natureza lógica, pois uma decisão tem que ser coerente, sob pena de nulidade, independentemente de disposição normativa, do mesmo modo que se exige a coerência lógica entre diferentes escalões normativos, sob pena de nulidade por inconstitucionalidade ou ilegalidade. Como diz Arruda Alvim, "é exatamente no instante em que é proferida a sentença que tal atividade lógica assume o momento fundamental de sua aplicação, no campo processo" ${ }^{53}$.

Embora não haja diferença do ponto de vista prático, eis que todos os embasamentos fáticos, axiológicos e normativos das decisões judiciais estão reunidas sob o termo "fundamento", é possível distinguir entre fundamento e motivação, na medida em que a lei processual determina a fixação dos limites subjetivos e objetivos de sua decisão. Ora, se fundamentação propriamente diz respeito aos limites objetivos, ou seja, aos aspectos lógico-jurídicos da decisão, pelo que ela deve estar amparada na lei e nos pressupostos lógicos que estabelecem a coerência entre o que se alega e o que se

\footnotetext{
${ }^{51}$ TARUFFO, Michele. La motivazione dela sentenza civile. Padova: CEDAM, 1975. p. 1.

52 HORAK, Franz. Zur rechtstheoretischen. Problematik der juristischen. Begruendung Von Entscheidungen, p. 1-26. In: SPRUNG, R. Entscheidungsbegründung, Austria: Insbruck, 1974.

${ }^{53}$ ARRUDA ALVIM, Manual ..., cit., p. 530.
} 
decide, a motivação refere-se aos limites subjetivos, os quais incorporam, além da apreciação subjetiva do julgador quanto às questões de fato, as influências decorrentes de suas valorações.

Outro critério de distinção é a presença do ato volitivo na decisão. Na medida em que a sentença é lógica, ela é fundamentada, se é ato de vontade, ela é motivada.

$\mathrm{O}$ art. 489, do novo CPC, fixa os elementos essenciais da sentença o relatório, a fundamentação e a decisão. Muito embora o dispositivo refira-se à sentença, é possível afirmar que todas as decisões judiciais devem seguir este modelo: relatório e pretensão, análise das questões de fato e de direito, e a decisão propriamente dita.

Esta determinação legal vem de encontro com a natureza lógica do processo. Segundo Arruda Alvim, "é exatamente no instante em que é proferida a sentença que tal atividade lógica assume o momento fundamental de sua aplicação, no campo processo" ${ }^{54}$.

$\mathrm{O}$ art. 489 determina que o relatório contenha, além dos nomes das partes e do registro das principais ocorrências havidas no andamento do processo, também a suma do pedido e da resposta do réu. Significa dizer que o juiz, ao sentenciar, deve estabelecer os limites subjetivos e objetivos de sua decisão. Com relação a estes últimos, deve explicitar os fatos, as provas produzidas, o pedido formulado e a resposta do réu.

O relatório é parte importantíssima da decisão, à qual não se tem dado a devida importância. O que se verifica na prática é a elaboração de relatórios extremamente sucintos, tendo-se, em várias oportunidades, a dispensa da obrigatoriedade de sua prolação, como, por exemplo, nos arts. 38 e 46, da Lei 9.099/95, sobre os Juizados Especiais Cíveis e Criminais, com aplicação também no âmbito dos Juizados Federais.

\section{DA COISA JULGADA RELATIVIZADA}

\footnotetext{
${ }^{54}$ ARRUDA ALVIM. Manual ..., cit., p. 542.

http://revistasapereaude.org/index.php/edicoes/ano-5-volume-3-outubro-2016 
A realidade dos conflitos que são mal resolvidos no judiciário afeta a todos principalmente no requisito da coisa julgada.

A celeridade deve ser pretendida pelo magistrado, mas que não pode ser o fundamento básico e único de um decisum ${ }^{55}$. O juiz deve buscar a solução rápida do caso $^{56}$, observando o contraditório e a ampla defesa, dentro de uma razoável duração do processo.

A relativização da coisa julgada é um instituto criado a partir da ideia de que o Judiciário é falho.

Essa verdade deve ser enfrentada, como situação real, e a relativização da coisa julgada, que foi criada para superar o erro judicial, encarada como naturalidade existente no processo. A alteração do entendimento do Tribunal ou até, mesmo, a alteração legal que também causará mudanças na forma de decidir uma lide.

O excessivo volume de processos que os magistrados detêm, quer pelo avolumando número de recursos que o sistema prevê, e quer pela morosidade natural que o próprio sistema processual civil nacional entronizou. Isso é uma causa do erro judiciário e ensejadora da relativização da coisa julgada.

\footnotetext{
${ }^{55}$ Deve-se tomar muito cuidado com essa ideia de celeridade que é buscada por todos, sabendo, como já referido, que a celeridade sem cautela passa a ser um problema e não uma solução, torna a análise mais problemática e perigosa, gerando injustiças. Umas das formas de utilizar a celeridade para descongestionar o Judiciário é a utilização das súmulas vinculantes e do efeito vinculante. Neste sentido, SANTOS, Boaventura de Souza. Para uma revolução democrática da justiça. $2^{\circ}$ ed., São Paulo: Cortez, 2008, p. 25.

${ }^{56}$ No sentido de agilidade, Boaventura de Souza Santos refere que o pacto de Estado, em favor de um Judiciário mais ágil e republicano, foi firmado pelas autoridades máximas dos três poderes da República Brasileira que convergiram em 11 compromissos fundamentais para o aperfeiçoamento do sistema judicial: 1) implementação da reforma constitucional do judiciário; 2) reforma do sistema recursal e dos procedimentos; 3) defensoria pública e acesso à justiça; 4) juizados especiais e justiça itinerante; 5) execução fiscal; 6) precatórios; 7) graves violações contra direitos humanos; 8)informatização; 9) produção de dados e indicadores estatísticos; 10) coerência entre a atuação administrativa e orientações jurisprudenciais já pacificadas; 11) incentivo à aplicação de penas alternativas. Um dos resultados mais visíveis do pacto foi a aprovação de alterações legislativas, notadamente no processo civil. Dentre as principais mudanças promovidas, destacamos: 1) Lei $\mathrm{n}^{\circ} 11.187 / 05$, agravos, racionaliza a utilização dos agravos que passam a ser julgados apenas no momento da apelação evitando o seu uso para fins protelatórios; 2) Lei $\mathrm{n}^{\circ} 11.232 / 05$, execução de títulos judiciais, unifica o processo de conhecimento, liquidação e execução de sentença dispensando notificação pessoal do réu após a citação; 3) Lei no 11.277/06, processos repetitivos, racionaliza o julgamento de processos repetitivos, permitindo ao juiz dispensar a citação do réu e julgar a acção improcedente se a controvérsia exclusivamente de direito e já tiver sido julgada improcedente em diversos casos idênticos submetidas ao mesmo juízo, 4) Lei $\mathrm{n}^{\circ}$ 11.341/06, processo eletrônico, disciplina a adoção de meios eletrônicos para a prática dos actos judiciais. (SANTOS, Boaventura de Souza. Para uma revolução democrática da justiça. $2^{\circ}$ ed., São Paulo: Cortez, 2008, p. 26).
} 
O Judiciário se encontra em situação difícil em decorrência da quantidade de demandas, ocorridas pelo amplo acesso à justiça e levando-se em conta o número mínimo de magistrados e seus auxiliares. Isso também aumenta levando em consideração a falta de boas condições que os servidores do judiciário tem para exercerem seu papel com eficiência. Apesar, hoje o judiciário caminha para a total digitalização dos processos, até a pouco tempo os funcionários do judiciário levavam o próprio computador para poder trabalhar com mais facilidade.

Os cidadãos buscam no Judiciário a resposta "correta"57 para suas demandas, confiam no judiciário, e os operadores do direito esperam o respeito ao atendimento dos princípios constitucionais e legais nas suas demandas. Um resultado diferente do mínimo esperado gera perplexidade frente ao verdadeiro descaso para com todos os princípios que norteiam o ordenamento jurídico ${ }^{58}$.

A doutrina apontou a relativização da coisa julgada como parte de solução do problema, mas para muitos não é bem aceita, por outro lado vemos como necessária para salvaguardar aos cidadãos, que são litigantes das injustiças e equívocos que possam vir a ocorrer.

Os casos em que os magistrados decidem de forma igual às ações repetitivas e que, em um caso em que o pleiteante venha a fazer uma nova reflexão naquele tipo de ação, que deveria ser observado cuidadosamente pelo Judiciário, mas que não o foi, pois o magistrado, por todo o volume de trabalho existente, acaba por não averiguar o pedido efetivado e acaba por decidir da mesma forma que tem feito em relação às outras demandas supostamente idênticas. É, nesses casos, que entra em jogo a utilidade da flexibilização da res iudicata.

A situação torna-se mais grave quando o juiz profere uma sentença de total improcedência em uma questão, o que pode motivar a decisão do Judiciário em conformidade com o art. 332 do novo Código de Processo Civil, em que o juiz poderá

\footnotetext{
${ }^{57}$ Sabe-se que resposta correta é algo utópico, pois a verdades distintas, a partir de uma das modalidades de observação pode ser diferente, cada uma das parte tem a sua idéia do seja correto, assim a expressão que se utiliza é no sentido de que o judiciário se manifeste e decida o conflito, ao menos, de forma satisfatória, respeitando aos princípios e às regras processuais existentes em nosso ordenamento jurídico. ${ }^{58}$ BOBIO, Norberto. Teoria do ordenamento jurídico. trad. Maria Celeste Cordeiro Leite dos Santos, $10^{\circ}$ ed., Brasília: Editora Universidade de Brasília, 1999, p. 71 e ss.
} 
decidir de forma idêntica à que tem feito em sentenças anteriores, dispensando-se, inclusive, a citação da parte adversa.

\section{CONCLUSÃO}

A realidade do Poder Judiciário é de transição entre um período de prosperidade e outro de depressão.

Para que o Poder Judiciário funcione adequadamente e possa solucionar os conflitos de interesses deve-se respeitar alguns institutos jurídicos primordiais que buscam antes de tudo a efetivação da palavra "justiça".

Esta concepção de celeridade do processo não pode deixar o direito material mal protegido em decorrência da vontade insana de velocidade para términos das demandas que crescem a cada dia.

O cidadão tem direito a uma sentença bem fundamentada, conforme prevê o art. 489, do novo CPC, demonstrando os argumentos jurídicos que foram utilizados pelo julgador, para que, assim, a parte possa, não só exercer o controle dessa decisão, se aceita ou não, impondo o recurso necessário.

O direito ao devido processo legal foi concebido como uma garantia assegurado pelo contraditório e pela ampla defesa, item que teve maior relevância no novo CPC, como os Artigos $7^{\circ}, 9^{\circ}$ e 10 , do CPC, todos previstos no capítulo das normas fundamentais do processo civil.

O próprio fenômeno jurídico da relativização da coisa julgada é decorrente de falhas do Poder Judiciário, ou da crise de seus institutos.

O aperfeiçoamento do processo com um novo Código seria muito relevante para os novos membros do Judiciário, preparando-os para o exercício desse cargo que ocupa relevância destacada frente à sociedade, por ser o responsável em levar, àqueles que tanto buscam a tão esperada realização da justiça, efetivação e respeito dos direitos que cada um dos cidadãos, pois um Judiciário, que não funcione bem, causa um prejuízo ainda maior para aquele que dele se socorreu. 
Portanto, cabe ao Estado a efetiva solução desse problema, não cabe falar-se que a sociedade tornou-se extremamente litigiosa. Para o cidadão pouco importa o acúmulo de trabalho que se agregou ao Poder Judiciário, pois o maior causador de processos na justiça é o próprio Estado, que não cumpre dever moral e legal. Este torna quase tudo em litígio contra o próprio cidadão.

\section{REFERÊNCIAS BIBLIOGRÁFICAS}

ALEXY, Robert. Teoria dos direitos fundamentais. trad. Virgilio Afonso da Silva, São Paulo: Malheiros, 2008.

ARAUJO CINTRA, Antonio Carlos de. Comentários ao código de processo civil. $4 \mathrm{v}$. arts: 332 a 475. Rio de Janeiro: Forense, 2003.

BARACHO, José Alfredo de Oliveira. Direito constitucional contemporâneo: homenagem ao Professor Paulo Bonavides/ Fernando Luiz Ximenes Rocha e Filomeno Moraes, organizadores. Belo Horizonte: Del Rey, 2005.

BAUMAN, Zygmunt. Modernidade e Ambivalência. Rio de Janiro: Jorge Zahar Editor, 1999.

BEDAUQE, José Roberto dos Santos. Direito e processo: influência do direito material sobre o processo. $4^{\circ}$ ed., rev. e ampli., São Paulo: Malheiros, 2006.

BEDAQUE, José Roberto dos Santos. Efetividade do processo e técnica processual. $2^{\circ}$ ed., São Paulo: Malheiros, 2007. 
BOBIO, Norberto. Teoria do ordenamento jurídico. trad. Maria Celeste Cordeiro Leite dos Santos, 10 ed., Brasília: Editora Universidade de Brasília, 1999.

CAMPBElL, C. The Romantic Ethic and the Spirit of Modern Consumerism. Oxford: Blackwell, 1987.

CANOTILHO, José Joaquim Gomes. Estudos sobre direitos fundamentais. $2^{\circ}$ ed., Portugal: Coimbra Editora, 2008.

CARRIÓ, Genaro R. e CARRIÓ, Alejandro D. El recurso extraordinario por sentencia arbitrria. Buenos Aires, Abeledo-perrot, 1983.

CARVALHO, Fabiano. EC n. 45: reafirmação da garantia da razoável duração do processo. In: WAMBIER, Teresa Arruda Alvim et al. (Coord.). Reforma do judiciário: primeiros ensaios críticos sobre a EC n. 45/2004. São Paulo: RT, 2005.

CASTANHEIRA NEVES, Antonio. O direito hoje em com que sentido? Lisboa: Editora Piaget, 2002.

CASTANHEIRA NEVES, Antonio. O instituto dos "assentos" e a função jurídica dos tribunais supremos. Coimbra, 1983.

CHIOVENDA, Giuseppe. Principios del derecho procesal. Madri: Reus, s/d.

CLÈVE, Clèmersom Merlin. A fiscalização abstrata da constitucionalidade no direito brasileiro. $2^{\circ}$ ed., São Paulo: RT, 2000.

DELACAMPAGNE, C. História da Filosofia no Século XX. Rio de Janeiro: Jorge Zahar Editor, 1995.

DINAMARCO, Cândido Rangel. A Instrumentalidade do Processo. $9^{\circ}$ ed., São Paulo: Malheiros, 2001.

DINAMARCO, Cândido Rangel. Instituições de Direito Processual Civil. 3 v. $2^{\circ}$ ed., São Paulo: Malheiros, 2002.

DUVERGER, Maurice. Constitutions et documents politiques. Paris: PUF, 1974. 
DWORKIN, Ronald. Levando os direitos a sério. trad. Nelson Boeira, São Paulo: Martins Fontes, 2002.

FEATHERSTONE. Cultura de consumo e Pós-modernismo. São Paulo: Studio Nobel, SESC, 1995.

GADAMER, Hans-Georg. Verdade e método II. trad. Enio Paulo Gianchini e Maria Sá Cavalcante Schuback, Petrópolis: Vozes, 2002.

GARAPON, Antonie. Bem julgar: ensaio sobre o ritual judiciário. Lisboa: Instituto Piaget, 1997.

GIDDENS. "A vida em uma sociedade pós-tradicional”, In: BECK, GIDDENS \& LASH, 1997.

MENDES, Gilmar Ferreira. Jurisdição constitucional. $3^{\circ}$ ed., São Paulo: Saraiva, 1999.

HARVEY, David. Condição pós-moderna. São Paulo: Edições Loyola, 1992.

HELLER, Agnes. Mas allá de la justicia. Barcelona: Editorial Crítica, versão espanhola de 1990.

JAYME, Erik. Cours général de droit intenacional prive. In recueil des cours, Académie de droit intenacional, t, 251, 1997.

KELSEN, Hans. Teoria pura do direito. 4º Ed., São Paulo: Martins Fontes, 1994.

KATO, Shelma Lombardi de. A crise do direito e o compromisso da libertação in Direito e justiça: A função social do Judiciário - org. José Eduardo Faria, $3^{\circ}$ ed., São Paulo: Ática, 1997.

KUMAR, Krishan. Da sociedade pós-industrial à pós-moderna. Rio de Janiro: Jorge Zahar Editor, 1997.

LABOULAYE, Edouard René Lefebvre de. Do Poder Judiciário in: O poder judiciário e a Constituição. Porto Alegre: coleção AJURIS 4, 1977. 
LIEBMAN, Enrico Tullio. Eficácia e Autoridade da Sentença e outros escritos sobre a Coisa Julgada. $3^{\circ}$ ed., Rio de Janeiro: Forense, 1984.

LYOTARD, Jean-François. O pós-moderno. Rio de Janeiro: Olympio Editora, 1986.

LOPES, José Reinaldo de Lima, in: FARIA, José Eduardo(coord.) [et. all]. Direito e justiça: A função social do judiciário, São Paulo: Ática, 1989.

LUHMANN, Niklas. Sitemi sociali: Fondamenti di una teoria generale. Bolonha:Il Mulino, 1990.

MARINONI, Luiz Guilherme. MITIDIERO, Daniel. Código de direito processual civil comentado. São Paulo: RT, 2008.

MARQUES, Claudia Lima. Contratos no código de defesa do consumidor: o novo regime das relações contratuais. 4. ed. rev., atual. e ampli., incluindo mais de 1.000 decisões jurisprudenciais. São Paulo, RT, 2002.

MARTINS, Eliezer Pereira. Segurança Jurídica e Certeza do Direito. publicado no site www.jus.com.br.

MIRANDA, Jorge. Teoria do estado e constituição. Rio de Janeiro, 2002.

MIRANDA, Pontes. Comentários ao Código de Processo Civil. Tomo V: arts. 444 a 475, 5. v. $3^{\circ}$ ed. Rio de Janeiro: Forense, 1997.

MONTESQUIEU, Charles de Secondat, Baron de. Do Espírito das Leis. São Paulo: Saraiva, 2000.

MORAES, Alexandre de. Direito constitucional. 19. ed. São Paulo: Atlas, 2006.

NERY JÚNIOR, Nelson. Princípios do processo civil na Constituição Federal. $7^{\circ}$ ed., São Paulo: RT, 2002.

NERY JÚNIOR, Nelson [et. all.]. Código de processo civil comentado e legislação extravagante. $10^{\circ}$ ed. rev., ampli. e atual., São Paulo: RT, 2007. 
NEVES, Antônio Castanheira. O direito hoje em com que sentido? Lisboa: Editora Piaget, 2002.

OLIVEIRA, Carlos Alberto Alvaro. Do formalismo no processo civil. $2^{\circ}$ ed., rev. e ampli., São Paulo: Saraiva, 2003.

OST, François. O tempo do direito. Lisboa: Instituto Piaget, 1999.

OST, François. O tempo do direito. Trad. Élcio Fernandes, Bauru: Edusc, 2005.

PERELMAN, Chaim. Ética e direito. São Paulo: Martins Fontes, 1996.

PICORDI, Nicola. La vocazione del nostro tempo per la giurisdizione. Revista trimestral de Diritto Procedura Civile. Giuffrè, 2004.

PIÇARRA, Nuno. A Separação dos Poderes como doutrina e Princípio Constitucional - Um contributo para o estudo das suas origens e evolução. Coimbra : Coimbra Editora, 1989.

PISANI, Andrea Proto. Revista da Escola da Magistratura do Rio de Janeiro. n. 16, 2001 .

PORTANOVA, Rui. Princípios do processo civil. $6^{\circ}$ ed., Porto Alegre: Livraria do Advogado, 2005.

REALE, Miguel. Crise do capitalismo e crise do Estado. São Paulo: Editora SENAC, 2000.

RIBEIRO, Darci Guimarães. La pretensión procesal y La tutela judicial efectiva. Barcelona: J.M.Bosch editor, 2004.

ROCCO, Ugo. Trattato di diritto processuale civile. V. I, $2^{\circ}$ ed., Torino: Topografia Sociale Torinese, 1966.

ROCHA, Álvaro Felipe Oxley da. Sociologia do direito: A magistratura no espelho. São Leopoldo: Editora UNISINOS, 2002. 
SANTOS, Boaventura de Souza. Para uma revolução democrática da justiça. $2^{\circ}$ ed., São Paulo: Cortez, 2008.

SANTOS, Boaventura de Souza. Pela Mão de Alice: O social e o político na pósmodernidade. São Paulo: Cortez, 1997.

SANTOS, Moacir Amaral. Primeiras linhas de direito processual civil. $7^{\circ}$ ed., São Paulo: Saraiva, 1980.

SANTOS, Moacyr Amaral dos. A prova judiciária no civil e no criminal. Rio de Janeiro: Max Limonad, 1952.

SCHOPENHAUER, Arthur. Como vencer um debate sem precisar ter razão: em 38 estratagemas. trad. Daniela Caldas e Olavo de Carvalho, Rio de Janeiro: Topbooks, 1997.

SILVA, Ovídio Araújo Baptista da. Curso de Processo Civil: processo de conhecimento. v. I. 5. ed. São Paulo: RT, 2001.

SILVA, Ovídio A. Baptista da. Da função à estrutura www.Baptistadasilva.com.br/artigos)

SILVA, Ovídio A. Baptista da. Jurisdição, direito material e processo. Forense, 2007.

SILVA, Ovídio A. Baptista da. In: Participação e processo. coord., Ada Pellegrini Grinover, São Paulo: RT, 1988.

SILVA, Ovídio A. Baptista da. Processo e ideologia. forense, 2004.

SILVA, José Afonso da. Curso de direito constitucional positivo. 20. ed. São Paulo: Malheiros, 2001.

SOUZA, Carlos Aurélio Mota de. Segurança Jurídica e Jurisprudência: um enfoque filosófico-jurídico. São Paulo : LTr, 1996.

STRECK, Lenio Luiz. Jurisdição constitucional e hermenêutica: uma nova crítica do direito. $2^{\circ}$ ed., Rio de Janeiro: Forense, 2004. 
THEODORO JÚNIOR, Humberto. Curso de Direito Processual Civil: Teoria do Direito Processual Civil e o Processo de Conhecimento. $39^{\circ}$ ed., Rio de Janeiro: Forense, 2003.

TOCQUEVILlE, Alexis de. La démocratie em Amérique. Paris: Garnier: Flammarion, 1951, t. II.

TARUFFO. La testimonianza della parte nel sistema dell'oralità. Giuffrè, 1974.

TARUFFO. Senso comune, esperienza e scienza nel ragionamento del giudice. In Revista trimestrale di diritto e procedura civile. trad. Cândido Rangel Dinamarco, Giuffrè, 2001.

VATTIMO, Gianni. O Fim da Modernidade: niilismo e hermenêutica na cultura pósmoderna. Lisboa: Editorial Presença, 1987.

WAMBIER, Tereza Arruda Alvim [et.al]. O dogma da coisa julgada: Hipóteses de relativização. São Paulo: RT, 2003. 